\title{
Ethanol Fraction of Corn Silk (Zea mays L.) to Decrease Uric Acid Levels in Male White Mice
}

\author{
Laila Susanti, Lilik Koernia Wahidah, Rizky Mu'arief \\ Department of Pharmacy, University of Tulang Bawang Lampung \\ Jln. Gajah Mada, No. 34 Kota Baru, Bandar Lampung \\ E-mail : lailasusanti80@gmail.com \\ 081323791775
}

\begin{abstract}
Corn silk (Zea mayz L.) were empirically used by the community in some regions as traditional remedies for hypertension, kidney stones,diabetes mellitus, urinary tractinfections and gout. This study aimed to determine the effect of corn silk ethanol fraction on decrease uric acid levels in male white mice.corn silk were extracted by macerate used $70 \%$ ethanol for 4 days. Urin acid test was performed on male mice induced by beef liver for 7 days.25 mice were grouped into 5 groups, groups dose I, II and III weregiven a fraction at a dose of $27.5 \mathrm{mg} / \mathrm{bwBB}, 55 \mathrm{mg} / \mathrm{bwBB}$ and $110 \mathrm{mg} /$ bwBB, control given Na.CMC $0.5 \%$ and as positive controls were given allopurinol dose of $13 \mathrm{mg} / \mathrm{bwBB}$. The five groups were treated orally 1 time a day for 7 days. Decreased uric acid levels were measured and observed on days 7 using an acid (easy touch). The results of ANOVA statistical analysis showed that negative controls gave a significant difference with positive controls, dose I, II and III because the sig value was $<0.05$ $(0,000)$. The results of the analysis of the advanced duncan, test showed that III doses was approached with positive control in reducing uric acid levels between groups. Conclusion of the trhee doses of fraction that have been carried out, namely trheatmen one $27,5 \mathrm{mg} / \mathrm{kgB}$, trheatment two $55 \mathrm{mg} / \mathrm{kgBB}$ and trheatment trhee $110 \mathrm{mg} / \mathrm{kgBB}$. Howaver, the most effective doses is trheatment trhee whichshows the most effective reduction namely at a doses of $110 \mathrm{mg} / \mathrm{kgBB}$.
\end{abstract}

Keywords: corn silk, beef liver, urin acid

\section{INTRODUCTION}

Uric acid is the end product of the degradation of purine compounds which in excess can cause arthritis, in normal conditions gout is very beneficial for the body which functions as an antioxidant and plays an important role in the cell regeneration process [1]. In an epidemiological study conducted over ten years it was concluded that there was an increase in the prevalence of gout and hyperuricemia. Although the prevalence of gout increases in both sexes, men have a higher incidence than women. In the age group $<65$ years, men have a prevalence four times higher than women and in the age group> 65 years men have a prevalence three times higher than women [2]. The symptoms of gout are pain, rheumatic pain, pain and tingling in the joints, with the characteristics of the joint swollen the skin appears red or purplish, feels warm and feels painful when touched [3]. One of the chemical drugs that are often used for the treatment of gout is allopurinol. Allopurinol reacts as a competitive inhibitor for the enzyme. This drug reacts to xanthine oxidase, an enzyme that catalyzes the degradation of 
hypoxanthine to xanthine and subsequently becomes uric acid. Inhibition of the oxidase enzyme causes hypoxanthine degradation to decrease and the resulting uric acid concentration decreases [4]. Decreased blood uric acid levels can be achieved in two ways, namely reducing the production of uric acid in the body (for example with allopurinol) or increasing uric acid secretion through uricosuric drugs such as probenecid and sulfinpirazone [5]. Side effects that often occur in the use of chemical drugs are irritation of the digestive tract, skin rash, hypersensitivity and crystallization of uric acid in the urine [4]. Based on the weakness of these chemical drugs, treatment is needed using traditional medicines, because in general it is considered safer than the use of chemical drugs. This is because traditional medicine has relatively low side effects rather than chemical drugs and can also be used as a guiding compound to find new drugs [6].

In general, Indonesian society has used corn hair boiled water as a traditional medicine to reduce blood uric acid levels. The use of corn hair in Indonesia is also useful in the treatment of various diseases such as hypertension, kidney stones, kidney inflammation, diabetes millitus, hepatitis, urinary tract infections, and gallbladder stones. Corn hair is known to contain phenols, steroids, flavonoids, tannins and alkaloids [2].

Based on the background above, the authors are interested in conducting research on the ethanol fraction of corn hair (Zea mays L.) on decreasing uric acid levels in male white mice. In this study, a fraction method was used which aims to separate the compounds contained in corn hair extract based on the level of polarity of the solvent used.

\section{RESEARCH METHODS}

\section{Tools and Materials}

The tools used in this study were animal scales, mice cages along with food and beverage places, $1 \mathrm{cc}$ syringes (Wego), analytical scales, rotary evaporator (EScientific), filter paper, $250 \mathrm{~mL}$ separating funnel (pyrex) , $100 \mathrm{~mL}$ measuring cup (pyrex), Erlenmeyer $250 \mathrm{~mL}$ (pyrex), stirring rod (pyrex), test tube (pyrex), glass $500 \mathrm{~mL}$ (pyrex), porcelain exchange rate (pyrex), uric acid strip (easy touch), GCU (easy touch).

The materials used were experimental mice (Zea mays L.) hair in the form of male mice, mice feed (pellets), $70 \%$ ethanol $\left(\mathrm{CH}_{3} \mathrm{CH}_{2} \mathrm{OH}\right)$, allopurinol (Generic), CMC (Bratachem), chloroform $\left(\mathrm{CHCl}_{3}\right), \mathrm{N}$ - hexan $\left(\mathrm{C}_{6} \mathrm{H}_{14}\right)$, sulfuric acid $\left(\mathrm{H}_{2} \mathrm{SO}_{4}\right)$.

\section{RESEARCH PROCEDURE}

\section{Plant Determination}

The determination of corn silk (Zea mays L.) will be carried out at the Botanical Laboratory, Department of Biology, Faculty of Mathematics and Natural Sciences (FMIPA) University of Lampung. The purpose of the determination is to prove that the species of the prospective corn silk are species (Zea mays $L$.).

\section{Simplicia Making}

Making corn hair simplicia is $1.1 \mathrm{~kg}$ of raw material collection, after collecting raw materials, then wet sorting is done to separate the simplicia from the dirt or foreign material attached to the corn hair. Then washing with running water is carried out with the aim of removing impurities attached to the corn hair. After that, a slicing is done to reduce the amount of water that is still attached to the simplicia before the rough crafting is carried out. The corn hair is then chopped and dried under the sun which is covered using a black cloth, then the dried hair of corn is produced

Non-specific parameter test (Zea mays L.) Simplicia

a. Water Content of (Zea mays L.) Simplicia

Testing the moisture content of corn hair simplicia. Analysis of corn hair moisture content using the oven method. Empty 
cup is dried in an oven with a temperature of $105 \mathrm{C}$ (for 20-30 minutes). The dry empty cup was then weighed with analytic naraca. A total of 10 grams of corn hair simplicia are put into a dry cup (A). The cup and the sample are dried in an oven 1050 for 2 hours then put into the desiccator for 2030 minutes, then weighed again (B). The cup is put back into the oven until a constant weight is obtained, provided the water content is not more than $4 \%$. The water content in the sample can be calculated by the following formula [7].

$=\frac{\text { initial weight of simplicia }- \text { average weighing }}{\text { initial weight of simplicia }} \times 100 \%$

\section{b. Ash content of (Zea mays L.) Simplicia}

weighed 3 grams of dried simplicia (W1), then put into the porcelain exchange rate that has been weighed first (W0). Lightly use the porcelain triangle on the direct fire until the charcoal runs out, cool it and weigh it to a fixed weight (W2). Calculate the ash content of the dried material provided that the value of ash is not more than $5 \%[7]$.

$$
\% A h c_{1} \quad=\frac{\mathrm{w} 2-\mathrm{w} 0}{\mathrm{w} 1} \times 100 \%
$$

information:

W0 = Empty cup weight (gram)

W1 = Initial simplicia weight (gram)

W2 = Weight of the cup + the simplicia that has been ignored (gram)

c. testing of insoluble ash in acids

Ash obtained from the determination of ash content, boiled with $25 \mathrm{~mL}$ dilute sulfuric acid $1 \mathrm{M}$ for 5 minutes, then collect the insoluble part in the acid, strain using filter paper (whatman 40) which has been weighed first, wash the insoluble part with hot water, dry in an oven at $1000 \mathrm{C}$ for 2 hours, then cool and weigh. Calculate the insoluble ash content in the acid against the dried material with the ash content requirement should not exceed 1\% [7].

$$
\begin{aligned}
& \% c_{1} \quad \begin{array}{l}
o \text { ir } \quad l \text { a } \\
\text { \%t } o \quad a h(g)
\end{array} \\
& =\frac{w \text { hto si }}{w \text { (g) }} \times 100 \%
\end{aligned}
$$

\section{Specific Parameter Test}

\section{a. Organoleptic examination}

Macroscopic examination was carried out by observing the shape, color, taste and odor of corn hair simplicia [7].

\section{Preparation of (Zea mays L.) Extract}

Simplicia of 400 gram dry corn hair is put into a dark glass container and added $70 \%$ ethanol, until the simplicia is completely submerged. Every 24 hours, stirring and solvent replacement are carried out by filtering until there is filtered pulp. The pulp obtained is immersed again with $70 \%$ ethanol, until the maserate color is the same as the solvent. To find out the perfect filtered substance, the last maserate was taken $5 \mathrm{~mL}$, put into a porcelain dish, heated over bunsen. If there is no sediment, the macerate is perfect. then the macerate obtained was evaporated using a rotary evaporator until the solvent evaporated completely and the extract became thick. Then the extract obtained is stored in a dark bottle.

\section{Preparation of (Zea mays L.) Fractions}

The thick extracts obtained were then fractionated with the addition of $96 \%$ ethanol, n-hexane, chloroform, and various solvents. Fractionation was carried out as follows: thick extract of corn hair plus $50 \mathrm{~mL}$ ethanol and $100 \mathrm{~mL}$ n-hexane, then shaken with a separating funnel to obtain n-hexane fraction and ethanol fraction and then separated. This process is carried out until the color of the $n$-hexane solvent does not change after shaking. The remaining ethanol fraction was added with $100 \mathrm{~mL}$ chloroform, then shaken with a separating funnel and then the chloroform and ethanol fractions were obtained and separated. This process is carried out until the color of the chloroform solvent does not change and two layers are formed after shaking. The ethanol fraction was then evaporated 


\section{JFL}

Jurnal Farmasi Lampung ～Vol. 8. No. 2 Desember 2019

with a rotary evaporator until a thick ethanol fraction was obtained

\section{Preparation of Allopurinol Solution}

One allopurinol tablet was inserted into the mortar and crushed until smooth, then weighed $13 \mathrm{mg}$ allopurinol tablet powder and then put into a $10 \mathrm{~mL}$ volumetric flask, to obtain a concentration equivalent to 1.3 $\mathrm{mg} / \mathrm{ml} 0.5 \%$ CMC solution was added to the boundary mark.

\section{Preparation of Animal Experiments}

The subjects of this study used 20-30 gram male mice as many as 25 mice which were divided into five experimental groups, namely negative control, positive control and three treatment controls which each group consisted of 5 animals. Before the research was carried out, all mice were kept for one week to adjust the environment, fed pellets and were given drinking water. Animals used as experimental animals are male white mice that are not deformed or injured and show normal behavior.

\section{Gout Testing}

Each mouse is adapted to the new enclosure environment in the laboratory, then fasted for 18 hours, but still given a drink. Then the uric acid levels were measured first using a gout test strip. Furthermore, all groups were given as much as $200 \mathrm{~g}$ of beef liver beef liver, given by oral $0.5 \mathrm{ml} / \mathrm{g}$ BB. After that, the uric acid levels were measured again at the same time each group was given treatment, namely:

$\mathrm{KN}$ : The experimental animals were given aquadest as a negative control

$\mathrm{KP}$ : Experimental animals were given allopurinol as a positive control

P1: Experimental animals were given ethanol fraction of corn hair at a dose of $27.5 \mathrm{mg} / \mathrm{kg} \mathrm{BW}$

P2: Experimental animals were given a water fraction of yellowish leaves at a dose of $55 \mathrm{mg} / \mathrm{kg} \mathrm{BW}$
P3: Experimental animals were given a water fraction of yellow leaves at a dose of $110 \mathrm{mg} / \mathrm{kg} \mathrm{BW}$

by giving the test once a day a week then the uric acid levels are checked again. With this design, it is possible for researchers to measure the effect of decreasing uric acid levels in the experimental group by comparing these groups with the positive control group.

\section{Data analysis}

The data obtained were analyzed by ANOVA analysis with a confidence level of $95 \%$. If the analysis shows a significant difference then the Ducan further test is continued to find out the difference in treatment levels. Data analysis using SPSS version 24 software.

\section{RESULTS AND DISCUSSION}

\section{Plant Determination}

Plant determination is a process in determining the name or type of plant specifically. Determination aims to get a species that is as specific as possible and right on target because plants have various types of varieties. The results of the determination carried out in the Biology Laboratory of the Biology Department of the University of Lampung showed that the plants used in this study were true of corn (Zea mays L.).

\section{Non-Specific Parameter Test}

Simplisia The hair of corn (Zea mays L.) is tested by non-specific parameters in an effort to ensure that the final product (drug, extract or extract product) has a fixed and specified parameter value (designed in the formula) first [7]. The standard non-specific parameter tests for simplicia to be carried out are three test parameters including water content, ash content and acid insoluble ash content. In this study the results were obtained: 
Table 1. Non-Specific Parameter Test Results

\begin{tabular}{c|l|c|c}
\hline No & Parameter & Results & Requirements \\
\hline 1 & $\begin{array}{l}\text { Water } \\
\text { Content }\end{array}$ & $0,4 \%$ & $\leq 4 \%$ \\
\hline 2 & Ash content & $4,6 \%$ & $\leq 5 \%$ \\
\hline 3 & $\begin{array}{c}\text { insoluble } \\
\text { ash content } \\
\text { in acids }\end{array}$ & $1 \%$ & $\leq 1 \%$ \\
\hline
\end{tabular}

The water content in this study obtained a yield of $0.4 \%$, which indicates that the water content in corn hair simplicia in normal limits does not exceed the standards set by the general standard parameters of medicinal plant extracts. If the water level exceeds a predetermined limit, it will cause simplicia to be overgrown with fungi and mold, which will reduce the quality of simplicia [7].

The ash content obtained from corn hair simplicia is $4.6 \%$ which shows that the ash content in the future coconut fruit simplicia does not exceed the predetermined standard value of $5 \%$. Ash levels that exceed the standard limit will cause a decrease in the quality of simplicia [7]. The level of acid insoluble ash obtained from corn hair simplicia is $1 \%$ which indicates that the levels in simplicia do not exceed the predetermined requirements.

\section{Specific Parameter Test}

Table 2. Specific Parameter Test Results

\begin{tabular}{c|c|l}
\hline No & Observed & Observation \\
\hline 1 & Smell & Typical of corn \\
\hline 2 & Colore & Brown \\
\hline 3 & Teste & Not teste \\
\hline
\end{tabular}

Organoleptic observation is a method of testing using the human senses as the main tool for observation. Organoleptic testing can provide an indication of decay, quality deterioration and other damage to simplicia. Organoleptic observers include smell, color, and taste. The results of organoleptic testing of corn hair can be seen in table 4.2 .

\section{Gout Testing}

The test animals that will be used are fasted for 8-12 hours but are still given drink so that the conditions of the test animals are the same and to reduce the effect of food consumed on the test preparation given in the study. Overall, the observations were carried out for 21 days, on the 7th day an initial uric acid level was checked using GCU easy touch. On the 8th to the 14th day induction with beef liver was carried out at 09.00 am and a uric acid level was checked. on the last day of induction at 4:00 p.m.

After checking uric acid levels in the adaptation phase, mice were induced with 200 grams of beef liver which was dissolved with $25 \mathrm{~mL}$ distilled water, then administered orally to mice as much as 0.5 $\mathrm{mL}$ per head for 1 consecutive week, then on the 7th day measured uric acid levels using the GCU easy touch tool presented in Table 3.

Table 3. Uric Acid Level After Induction

\begin{tabular}{l|l|l|l|l|l|l}
\hline \multirow{2}{*}{$\begin{array}{l}\text { Treatm } \\
\text { ent }\end{array}$} & \multicolumn{4}{|c|}{ Uric acid levels after induction } & Ave \\
\cline { 2 - 6 } & 1 & 2 & 3 & 4 & 5 & $\begin{array}{l}\text { rag } \\
\text { e }\end{array}$ \\
\hline K N & 5,5 & 5,4 & 5,6 & 5,5 & 5,3 & 5,46 \\
\hline K P & 5,6 & 5,5 & 5,5 & 5,4 & 5,6 & 5,52 \\
\hline P 1 & 5,1 & 5,3 & 5,2 & 5,4 & 5,6 & 5,32 \\
\hline P 2 & 5 & 5,2 & 5,4 & 5,1 & 5,2 & 5,18 \\
\hline P 3 & 5,1 & 5,3 & 5,2 & 5,2 & 5,5 & 5,28 \\
\hline
\end{tabular}

Table 4. Uric Acid Level After Treatment

\begin{tabular}{l|l|l|l|l|l|c}
\hline \multirow{2}{*}{$\begin{array}{l}\text { Treat } \\
\text { ment }\end{array}$} & \multicolumn{4}{|c|}{ Uric acid levels after treatment } & \multirow{2}{*}{$\begin{array}{c}\text { Ave } \\
\text { rage }\end{array}$} \\
\cline { 2 - 6 } & 1 & 2 & 3 & 4 & 5 & \\
\hline $\mathrm{K} \mathrm{N}$ & 5,3 & 5,4 & 5,3 & 5,4 & 5,2 & 5,32 \\
\hline $\mathrm{K} \mathrm{P}$ & 3,2 & 3,3 & 3 & 3,2 & 3,3 & 3,2 \\
\hline $\mathrm{P} 1$ & 4 & 3,9 & 3,8 & 3,9 & 3,8 & 3,88 \\
\hline $\mathrm{P} \mathrm{2}$ & 3,7 & 3,6 & 3,7 & 3,5 & 3,6 & 3,62 \\
\hline $\mathrm{P} \mathrm{3}$ & 3,4 & 3,2 & 3,3 & 3,2 & 3,4 & 3,3 \\
\hline
\end{tabular}

Information :

$\mathrm{KN}$ : Negative Control 
KP: Positive Control

P1 : Giving ethanol fraction of corn silk dose $27,5 \mathrm{mg} / \mathrm{kgBB}$.

P2 :Giving ethanol fraction of corn silk dose $55 \mathrm{mg} / \mathrm{kgBB}$.

P3 : Giving ethanol fraction corn silk dose $110 \mathrm{mg} / \mathrm{kgBB}$ mice.

Based on the test results in the table 4.4 it can be seen that from the three dose treatments that have been carried out, the average value of uric acid that is approached with positive control is obtained by treatment three (PIII) at a dose of $110 \mathrm{mg} / \mathrm{kgBB}$ which is an average value of $3.3 \mathrm{mg} / \mathrm{dl}$ where in the positive control the average value is $3.2 \mathrm{mg} / \mathrm{dl}$.

Table 5. Results of the percentage decrease in uric acid levels.

\begin{tabular}{c|c|c|c}
\hline Treatment & $\begin{array}{c}\text { Average } \\
\text { uric acid } \\
\text { level after } \\
\text { induction }\end{array}$ & $\begin{array}{c}\text { The } \\
\text { average } \\
\text { uric acid } \\
\text { level after } \\
\text { treatment }\end{array}$ & $\begin{array}{c}\text { Percentage } \\
\text { Decrease } \\
\text { in Uric Acid } \\
\text { Levels (\%) }\end{array}$ \\
\hline KN & $5,, 46$ & 5,32 & 2,56 \\
\hline KP & 5,52 & 3,2 & 39,85 \\
\hline P1 & 5,32 & 3,88 & 27,06 \\
\hline P2 & 5,18 & 3,62 & 30,11 \\
\hline P3 & 5,28 & 3,3 & 37,5 \\
\hline
\end{tabular}

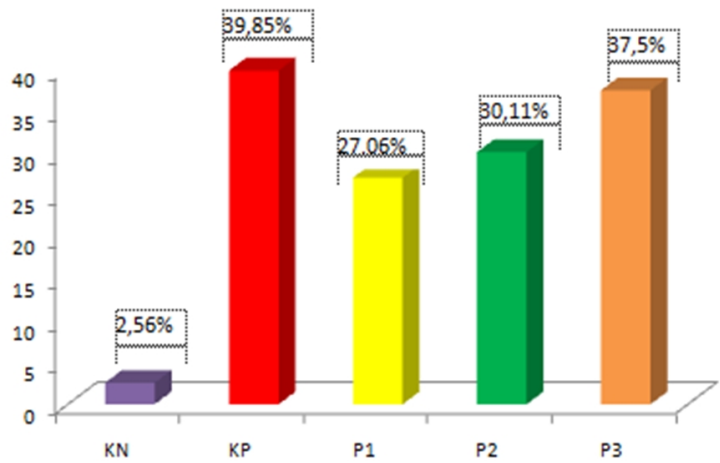

Figure 1. Percentage of Uric Acid Reduction

Based on the results of the test it can be seen the percentage decrease in uric acid levels in the diagram diagram 4.1. The highest decrease in uric acid levels was shown in the P3 group, namely with the ethanol fraction of corn hair at a dose of $110 \mathrm{mg} / \mathrm{dL}$, with a percentage reduction in uric acid levels of $37.5 \%$, which showed effective results in reducing uric acid levels. and approaching KP allopurinol $13 \mathrm{mg} /$ $\mathrm{kgBW}$ with a percentage decrease in uric acid levels $39.85 \%$. At P1 and P2 the dose of corn hair ethanol fraction was $27.5 \mathrm{mg} /$ $\mathrm{kgBB}$ and the provision of corn hair ethanol fraction $55 \mathrm{mg} / \mathrm{kgBB}$ had a percentage decrease in uric acid levels of $27.06 \%$ and $30.11 \%$, respectively uric acid is lower than $\mathrm{KP}$ and $\mathrm{P} 3$.

\section{Review of Pharmacological Activities Ethanol Fraction of Corn Hair}

Based on phytochemical screening, what has been done shows positive results for the class of flavonoids, marked by the formation of orange in the amyl alcohol layer, and positive for steroid / triterpenoid compounds [8].

Some flavonoids can inhibit the action of the xanthine oxidase enzyme. The xanthine oxidase enzyme is an enzyme that plays a role in the catalysis of hypoxanthine into xanthine and xanthine into uric acid, so that when the enzyme works it is inhibited the production of acidic acid will decrease [9].

This is thought to be due to the presence of hydroxyl $(-\mathrm{OH})$ functional groups present in flavonoids, where at least one hydroxyl functional group must be able to inhibit the action of the xanthine oxidase enzyme. In the structure of flavonoids with the presence of hydroxyl groups on C-5 or C 7 and the presence of a double bond between C2 = C3 which allows an addition reaction (oxidase by xanthine oxidase) [10]. 
<smiles>O=c1cc(-c2ccc(O)cc2)oc2cc(O)cc(O)c12</smiles>

Figure 2. Structure of Flavonoids [11].

\section{CONCLUSIONS AND SUGGESTION}

\section{Conclusion}

Based on the results of research conducted, it can be concluded that:

1. Based on the results of research that has been done it can be concluded that the administration of ethanol fraction of corn hair can have an effect as a decrease in uric acid levels.

2. Of the three doses of fraction that have been carried out, namely treatment one $27.5 \mathrm{mg} \mathrm{/} \mathrm{kgBB}$, treatment two $55 \mathrm{mg} / \mathrm{kgBB}$, and treatment three $110 \mathrm{mg} / \mathrm{kgBB}$. However, the most effective dose is treatment III which shows the most effective reduction, namely at a dose of $110 \mathrm{mg} / \mathrm{kgBB}$.

\section{Suggestion}

Based on the results of the research that has been conducted, further research is recommended to:

1. For further research it is recommended to isolate flavonoids contained in corn hair (Zea mayz L.) which have the effect of reducing uric acid levels.

2. It is necessary to make pharmaceutical preparations from the ethanol fraction of corn hair (Zea mays L.) which can give the effect of decreasing uric acid levels in the form of traditional medicines that are easy to use everyday such as powder, capsules, tablets and so on.

\section{ACKNOWLEDGMENTS}

Thank you to pharmacology and pharmacology chemistry laboratory staff at Tulang Bawang Lampung University and Lampung University Chemistry Laboratory.

\section{REFERENCES}

[1]. Neti Suriana. 2014. Herbal Sakti Atasi Asam Urat. Jakarta: Mutiara Allamah Utama.

[2]. Lovira Hamzah, Helmi Arifin, Azram A. 2014. Pengaruh Ekstrak Etanol Rambut Jagung (Zea Mays L.) Terhadap Kadar Asam Urat Darah Mencit Putih Jantan Hiperurisemia. Perkembangan Terkini Sains Farmasi dan Klinik. IV:282-93.

[3]. Junaidi I. 2006.Rematik dan Asam Urat. Jakarta: Bhuana IImu Komputer.

[4]. Sukanandar EY, Andrajati R, Adnyana IK, Setiadi AP, Sigit JI, Kusnandar.2009. Iso Farmakoterapi. Jakarta: PT. ISFI.

[5]. Restusari L, Arifin H, Dachriyunus YY. 2014. Pengaruh Fraksi Air Ekstrak Etanol Daun Salam (Syzygium polyanthum Wight.) Terhadap Kadar Asam Urat Darah Pada Tikus Putih Jantan Hiperurisemia - Diabetes. Perkembangan Terkini Sains Farmasi Klinik IV. 220-7.

[6]. Sari LORK. 2006. Pemanfaatan Obat Tradisional dengan Pertimbangan Manfaat Dan Keamanannya. Majalah IImu Kefarmasian. 3(1):1-7.

[7]. Departemen Kesehatan. 2000. Parameter Standar Umum Ekstrak Tumbuhan Obat. Jakarta: Departemen kesehatan. 


\section{JFL}

[8]. Wirasutisna KR, Fidrianny I,

Rahmayani A. 2012. Telaah

Kandungan Kimia Rambut Jagung

(Zea mays L.). Acta Pharmaceutika Indonesia.37(1).

[9]. Hardian, Sulistiarini R, Rijai L. 2014. Aktivitas Antihiperurisemia Ekstrak Daun Lada (piper nigrum L.) Pada Mencit (Mus musculus L.). Jurnal Trop Pharmaceutical Chemical.2(5).

[10]. Cos P. 1998. Structur Relationship a nd Classification of Flavonoids as Inhibitors of Xantine Oxidase and Superoxide Scavengers.Journal of Natural Products.61(1).

[11]. Kumar et al. 2011. Areview of Phytchemistry and Pharmacology Flavonoids. Internationle

Pharmaceuticale Sciencie.12(2). 